\title{
Refractive Errors and Visual Anomalies in Schoolchildren in the Kavrepalanchowk District
}

\author{
Marasini $\mathrm{S}^{1}$, Sharma $\mathrm{R}^{2}$, Sthapit PR ${ }^{3}$, Sharma $\mathrm{D}^{4}$, Koju $\mathrm{U}^{5}$, Thapa $\mathrm{G}^{6}$, Nepal BP
}

${ }^{1-7}$ Department of Ophthalmology

Dhulikhel Hospital,

Kathmandu University Hospital

Dhulikhel, Nepal

\section{Corresponding author}

Sanjay Marasini, B. Optom

Department of Opthalmology

Dhulikhel Hospital - Kathmandu University Hospital

Dhulikhel, Nepal

Email. thesanzay@gmail.com

Kathmandu Univ Med J 2010;9(32):362-6

\begin{abstract}
Background

Schoolchildren form an important target group for a nation, as any ocular morbidity in this age group has huge physical, psychological and socio-economical implications. Childhood eye disorders can contribute to the burden of blindness in any society. This study aims to highlight the prevalence of ocular morbidity in governmental schools in a sub-urbanised area of Nepal, in relation to ethnic variation.
\end{abstract}

\section{Methods}

A descriptive study, and the study population used were schoolchildren who were examined in their schools and afterwards referred to the hospital if required. Presenting and best corrected visual acuity, refraction, binocularity assessment, anterior and posterior segment evaluation was carried out. Data was analysed statistically using SPSS software, version 14.

\section{Results}

We examined 1,802 school children. The mean age was $10.78 \pm 3.61$ years. Ocular abnormality was detected in $11.7 \%$. Low vision and blindness was rare $(0.11 \%$ and $0.05 \%)$. Ocular morbidities were more common in Newar communities (3.71\%) followed by Brahamans (3.38\%). Lid abnormalities were the most common (3.55\%), and morbidities in each ethnicity were followed by refractive errors $(3 \%)$, conjunctival abnormalities $(1.10 \%)$, strabismus $(0.88 \%)$ and amblyopia $(0.33 \%)$. Refractive errors were most common among Newar communities $(1.16 \%)$ at almost twice as many Brahamans $(0.61 \%)$ followed by Mongolians $(0.49 \%)$. Convergence insufficiency was detected in $2.49 \%(p<0.01)$.

\section{Conclusions}

Ocular morbidities are common in children in Kavhrepalanchowk District with lid abnormalities being the most common issue, probably due to a lack of hygienic practice. Ethnic variation of ocular morbidities is an important observation mostly for refractive error and strabismus.

\section{Key Words}

blepharitis, blindness, ethnicity, oculo-visual, visual acuity 


\section{INTRODUCTION}

School screenings for eye diseases is aimed to identify children who are at risk of eye diseases at a sub-clinical stageandwhichcanbediagnosed with theapplication oftests, examinationsandprocedurescarriedoutrapidly on alargescale. AlthoughVision2020:therighttosight imposes a mandate to abolish the preventable causes of blindness, fewer infrastructures and resources are

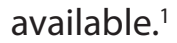

Schoolchildrenformanimportant targetgroupforthe nation as any ocular morbidity in this age group has huge physical, psychological and socio-economical implications. Earlydiagnosisoftheocularmorbidityand appositecorrectionhelpsinoverallvisualdevelopment and better academic performances as well. In a study conductedinschoolchildreninKathmandu;anurbanized area; the prevalence of ocularmorbidity was observed in $11 \% .{ }^{2}$ Another study claims that refractive errors are moreprevalentinschoolchildrenofprivateschoolsover students at government schools. ${ }^{3}$

Population-based refractive error surveys in children wereconductedinChina, Nepal,andChilewiththesame investigative protocols. The aim was to elucidate the differencesinthe prevalence of refractiveerrorsacross differentgeographicdistributionandethnicorigins, as wellasculturalsettingsinordertogetdirectlycomparable datafromdifferentcountries.Thesestudiessuggestedthat theprevalence ofmyopiaismuch higherintheChinese and the Caucasian population ofChile, incomparisonto theNepalesepopulation.ItalsosuggestedthatCaucasian populationsare morelikely to behyperopic than Asian populations. ${ }^{4,5,6}$ Onestudyhasexploredthedistribution of refractive errors in different ethnic groups of Nepal. Theyconcludedthatrefractiveerrorsaremoreprevalentin Newars and Aryans.?

The aim of the study is to explore and document the prevalence of ocular morbidity in government schoolchildrenoftheKavrepalanchowkDistrict.Findings ofthepresentstudyareexpectedtohighlighttheethnic variation in the prevalence of ocular morbidity.

\section{METHODS}

This is a descriptive study conducted in government schools. Thechildrenbelongedtodifferentsocioeconomic strata and ethnic groups. Eight schools were selected randomlyin Dhulikheland nearby villages. Permission was sought from the headteachers of the school after whichadatetoconductthescreeningwasagreedupon. Information was distributedamongstudentsaboutthe dayofscreeningsoastoinvolvethemaximumnumber ofstudents. Allthechildrenattendingschoolduringthe screening wereincluded in the study.Very few of them were unwilling to participate and absences in the class were excluded from the study. A team from Dhulikhel Hospital - Kathmandu University Hospital (DH-KUH) whichincludedanophthalmologist, anoptometrist, an ophthalmic assistant and two medical interns ran the programme.Thescreening programmestartedin 2007. Thispaperconsistsoftheanalysisofdatafromtheschools screened between April 2007 to August 2010.

PresentingdistancevisualacuitywastestedbySnellen's chartatadistanceof20feet, followedbypinholeincaseof reducedvisualacuity.Childrenwhosevisualacuitycould notberecordedwereexamined withtorchlightinasemi darkroomandnotedwhethertheireyeswouldfollowlight. In addition retinoscopies were carried out on all of the schoolchildrentoruleoutanyrefractiveerrors. Allother studentswith a visualacuity of $\leq 20 / 30$ were referred to $\mathrm{DH}-\mathrm{KUH}$ withareferralnotewherecycloplegicrefraction was carried out. All the students with referral notes presented to the hospital.

Cover test, convergence test, extra ocular motility examination was performed on every child. Any child found to have strabismus; poor fixation and any other abnormality was referred to the hospital for further evaluationandmanagement.Ophthalmolcopywasdone in all.

The standards for quantifying refractive error that we usedwereasfollows:myopiawasconsideredtobeamean sphericalequivalentrefractiveerrorof $\geq 0.50 \mathrm{DS}$; hyperopia was defined as $\geq+1.00 \mathrm{D}$; astigmatism was defined as $\geq$ 1.00DC;andanisometropia(meansphere)wasdefined as a difference of $\geq 1.00$ Diopters. Data analysis was conducted withStatisticalPackagefortheSocialSciences (SPSS) version 14.

\section{RESULTS}

A total number of 1,802 children participated in the study among which 959 (53.2\%) were female and 843 (46.8\%)male.Themeanagewas 10.78 \pm 3.61 years(range: 3 years to 22 years). Of the total, 173 (9.6\%) were preprimary and $771(42.8 \%)$ were primary level students. The number of children under five years old was 173 (4.5\%).Ocularabnormalitywas detectedin $210(11.7 \%)$ ofwhich91(43.33\%)weremaleand 119 female(56.66\%), statisticallynotsignificant $\left(x^{2}\right.$ test $\left.=1.135, d f=1, p=0.287\right)$.

Bestcorrectednormaltosubnormalvisualacuity $(20 / 20$ to $20 / 60$ ) in the better eye was observed in 1,741 $(96.61 \%)$ children. Two children $(0.11 \%)$ had low vision 
(>20/60 to 20/400) and one (0.05\%) child remained blind (>20/400)evenafter treatment.Thedistribution of presentingandbestcorrectedvisualacuityispresentedin Table 1.

Table 1. Number and percentage of PVA and BCVA.

\begin{tabular}{lcc|}
\hline \multirow{2}{*}{ Visual acuity } & \multicolumn{2}{c}{ (No. and \%) } \\
& PVA & BCVA \\
$20 / 20$ & $1646(91.3)$ & $1738(96.44)$ \\
$>20 / 40$ & $78(4.3)$ & $3(0.16)$ \\
$>20 / 200$ & $16(0.9)$ & $2(0.11)$ \\
$>20 / 400$ & $2(0.1)$ & $0(0.00)$ \\
$<20 / 400$ & $2(0.1)$ & $1(0.05)$ \\
Believed sighted (uncooperative) & $58(3.2)$ & $58(3.21)$ \\
Total & $1802(100)$ & $1802(100)$
\end{tabular}

PVA, presentingvisualacuity;BCVA, bestcorrectedvisual acuity; believedsighted,childrenonwhomappropriate visual acuity could not be tested because of their uncooperative nature.

OcularmorbiditiesweremostcommoninNewars(3.71\%) followed by Brahamans (3.38\%) and Chhetris (2.05\%). Lid abnormalities were the most common (3.55\%) morbiditiesineachethnicityfollowedbyrefractiveerrors (3\%), conjunctival abnormalities $(1.10 \%)$, strabismus (0.88\%)andamblyopia(6cases, $0.33 \%$ ). Thedistribution of different types of ocular morbidity with ethnicity is presented in Table 2. vision $(0.11 \%)$ and blindness $(0.05 \%)$ was rare. Ocular abnormalities were more common in Brahamans than Newar communities and other ethnicities.

Theoverall prevalenceofocularmorbidityobserved in the study is similar to that of Nepal. (11\%). ${ }^{2}$ The study foundthatthemajoroculardisorderswererefractiveerror, strabismus, traumaticeyeinjuries, vitaminAdeficiency andothercongenitalanomaliesinastudysampleof1,100 schoolchildren.Weobservedthemajoroculardisordersto beexternaleyeinfections, refractiveerrorandstrabismus, conjunctivaland corneal disorders. Wedid notfindany caseswithvitaminAdeficiencyorcongenitalanomalies.

In Nepal, vitamin A capsule supplementation as well aseducational programmeshavebeeneffectiveforthe last 12 years, asagovernmentinitiativeincollaboration with various organisations, and as a result, vitamin $\mathrm{A}$ consumption has increased significantly. ${ }^{8}$ The reason behindourobservationwithnocasesrelatedtovitamin $A$ deficiencycanbeaccountedforapositiveoutcomeofthis nationaleffort.Ocularmorbiditythatwasobservedinthis studyislowerthanthatofNigeria(15.5\%). ${ }^{9}$ Thisdifference mightbebecauseofthevaryingurbanisedpopulationand ethnic differences.InEthiopia the prevalence of ocular morbidity in children was very high (55\% to $63 \%$ ); followed bytrachoma which wasalsotheleading cause forit(34\%to54\%);followed byothercommondisorders

Table 2. Number and percentage of ocular morbidity pattern in different ethnic groups

\begin{tabular}{|c|c|c|c|c|c|c|}
\hline \multirow{2}{*}{ Type of ocular morbidity } & \multicolumn{3}{|c|}{ No. (\%) } & \multirow[b]{2}{*}{ Chhetri } & \multirow[b]{2}{*}{ Others } & \multirow[b]{2}{*}{ Total (\%) } \\
\hline & Brahamans & Newars & Mangoloids & & & \\
\hline Refractive error & $11(0.61)$ & $21(1.16)$ & $9(0.49)$ & $8(0.44)$ & $4(0.22)$ & $53(2.94)$ \\
\hline Myopia & $7(0.38)$ & $18(0.99)$ & $6(0.33)$ & $5(0.27)$ & $3(0.16)$ & $39(2.16)$ \\
\hline Hyperopia & $3(0.16)$ & $3(0.16)$ & $3(0.16)$ & $2(0.11)$ & $1(0.05)$ & $12(0.66)$ \\
\hline Astigmatism & $1(0.05)$ & $7(0.38)$ & $1(0.05)$ & $5(0.27)$ & $1(0.05)$ & $15(0.83)$ \\
\hline Convergence insufficiency & $13(0.72)$ & $17(0.94)$ & $7(0.38)$ & $8(0.44)$ & $0(0.00)$ & $45(2.49)$ \\
\hline Strabismus & $9(0.49)$ & $3(0.16)$ & $1(0.05)$ & $3(0.16)$ & $0(0.00)$ & $16(0.88)$ \\
\hline Lid disorders & $17(0.94)$ & $20(1.10)$ & $10(0.55)$ & $12(0.66)$ & $5(0.27)$ & $64(3.55)$ \\
\hline Conjunctival disorders & $7(0.38)$ & $2(0.11)$ & $4(0.22)$ & $5(0.27)$ & $2(0.11)$ & $20(1.10)$ \\
\hline Corneal disorders & $2(0.11)$ & $0(0.00)$ & $1(0.05)$ & $0(0.00)$ & $0(0.00)$ & $3(0.16)$ \\
\hline Episcleritis & $1(0.05)$ & $3(0.16)$ & $1(0.05)$ & $1(0.05)$ & $1(0.05)$ & $7(0.38)$ \\
\hline Optic atrophy & $1(0.05)$ & $0(0.00)$ & $0(0.00)$ & $0(0.00)$ & $0(0.00)$ & $1(0.05)$ \\
\hline Chemical injury & $0(0.00)$ & $1(0.05)$ & $0(0.00)$ & $0(0.00)$ & $0(0.00)$ & $1(0.05)$ \\
\hline Total (\%) & $61(3.38)$ & $67(3.71)$ & $33(1.83)$ & $37(2.05)$ & $12(0.66)$ & $210(11.7)$ \\
\hline
\end{tabular}

\section{DISCUSSION}

Only $98(5.4 \%)$ children had presenting visual acuity of less than $20 / 20$ and 58 (3.21\%) children could not be tested withSnellen'schart.Six $(0.33 \%)$ childrencouldnot becorrectedto20/30orbetterbecauseofamblyopia.Low suchas refractiveerror (6.3\%to 12\%); strabismus (0.8\% to $4.4 \%)$; corneal opacity (1.3\% to $1.8 \%)$; conjunctivitis (2.3\% to $15.3 \%)$; and xerophthalmia(1.1\%to $1.7 \%)$.This might be because of the lowsocio-economicleveland 
underdeveloped health infrastructure. ${ }^{10,11}$

Lidabnormalitiesinourstudywerethemostcommon. Ourfindings(3.55\%)donotcomparewellwithNigerian $(0.6 \%)^{9}$ and Durban, South African $(2.7 \%)$ studies. $^{12}$ Weassumethatpoorhygienicpracticeintheruralareas in Kavhrepalanchowk District is attributable to the higherfrequencyoflidabnormalities, blepharitisbeing themostcommon disorder,followed bymeibominitis. Conjunctival, corneal and retinal disorders were low.

Convergenceinsufficiencywasacommondisorderwith higher prevalence in secondary level students (1.77\%) than in primary level students $(0.721 \%)$. This may be attributabletotheincreasedreadinghours of students atsecondaryschool.Itisjustifiablebecausenoneofthe pre-primary students had $\mathrm{Cl}$. Cl was more common in thefemalepopulation ofthestudy $(P>0.005)$. Hormonal changes might have had some role to play in this observationbecausemostofthegirls $(499,52 \%)$ werein there menarche age (11-13 years).

We detected a corneal ulcer in one child $(0.05 \%)$ who wasattendingschoolwithouttreatment.Cornealopacity followingtraumawereobservedin $0.11 \%$, acomparable rate as that of $0.12 \%$ of Mechizone study. A higher rate (0.3\%)isobservedinNigeria.Perhaps, differentfidgeting nature of children contributes to this difference in observation.

Conjunctivitis was seen in $0.65 \%$; much less than that in India $(4.6 \%)^{13}$ and Nigeria (7.4\%- 16\%). ${ }^{9,14}$ This discrepancymightbebecauseofthedifferenceinstudy seasons or the very shortduration of thestudy disease.

Aryanswerefoundtohavemoreprevalenceofstrabismus incomparisontootherethnicitieswithalternatediverging strabismusbeingcommon;anobservationsimilarlynoted by Nepaletal. ${ }^{2}$ Itwasmorecommoninfemales. Different genetic make-up, racial factors and environmental influencesareconsideredforthisvariation. Prevalence of strabismuswashigher ( $0.88 \%$ ) in ourstudy than that reported in Nigeria (0.3\%) and lowerthan that of Mechi zone $(2.1 \%)$, Kathmandu (1.63\%) and Durban (1.3\%) $)^{12}$ butitwascomparabletothatofIndia(0.5\%). ${ }^{13}$ Refractive errorsandstrabismusarebelievedtohavearelativelylower incidencein blackskinnedraceswith hereditaryfactors being blamed for this peculiar epidemiology. ${ }^{14}$

The 1981 blindnesssurveyofNepalidentifiedrefractive error based on pinhole correction as a primary ocular disorderin $1.3 \%$ ofthe39,887 population.Ourfiguresare higher(3\%).Itmightbebecauseourstudypopulationwas schoolchildrenwhoareexposedtonearworkmostofthe timewhereasblindnesssurveywasconductedinall-age population.Moreovertheblindnesssurveywasconducted morethan20yearsagoandtheremightbetheincreasing trend in prevalence of refractive error because of the increasedliteracyrateandurbanisationofthecountry.The effectofurbanisationinrefractiveerrorhasbeenreported in studies conducted in India. They have shown that theprevalenceofmyopiaand hyperopiain urban India (7.1\%and $7.7 \%$ ) washigherthaninrurallndia(4.1\%and $0.8 \%) .{ }^{15,16}$ Weobservethesimilartrendinrefractiveerror prevalenceinKathmandu (8.1\%); anurbanizedareaand our study (3\%); in a rural location.

TheMechizonestudy concluded that thereisverylittle (1.3\%) prevalenceofrefractiveerrorinchildreninNepal, but the prevalence was observed to be much higher in Kathmandu(8.1\%)andPokhara(6.43\%)andthepresent study (3\%). This discrepancy might be explained in termsofthestudypopulationbecausetheformerwasa populationbasedstudyandthelatterwereschool-based study. Refractive error prevalence seen in our study is lowerthanthatofAjaiyeobaAletal.(5.8\%)inNigeria, and higherthanthatofNaidooKSetal.(1.82\%)inSouthAfrica andKehindeAVetal.(1.7\%)inNigeria.Thesedifferences probablyreflecttheuniquehereditaryinfluencesamong variousgroupsand the differentenvironmentalfactors. RefractiveerrorismoreprevalentinNewarcommunity; a study similarly noted by Karki KJD et al. ${ }^{7}$ There is an agreementthattheprevalenceofastigmatismliesmore inNewars. Theyemphasisethatthereareindeedethnic variations particularlymarkedfor refractiveerrors. Our studysupportsthisobservation.Otherstudiessupport thattherearesignificantdifferencesintherefractiveerror prevalenceasafunction ofethnicity,evenaftercontrolling for age and sex. ${ }^{17,18}$

Theprevalenceofrefractiveerrorinpre-primary,primary andsecondaryschoolchildrenwas $0.33 \%, 0.94 \%$ and $1.66 \%$ respectively.Therewasanage-relatedshiftinrefractive errorfromhyperopiainyoungerchildren(0.16\%in7year olds) towards myopia in older ( $0.22 \%$ in 14 year olds). Similarlyastigmatismisalso seen to be moreprevalent in theageabove 12 years accounting for $0.61 \%$. Higher prevalenceofexternaleyeinfectionsmayleadtotheuse offingerstorubeyes,leadingtotopographicalvariationin thecorneaandleadingtoastigmatism. Refractiveerroras a function of age is similarly observed by Khalaj Metal. In Iran ${ }^{19}$ and in other studies in China and Hong Kong. In various Chinese studies, 37\% of children aged 6-12 years, and50\% ofchildrenaged13-17yearssufferedfrom myopia.Similarly,inHongKong9\%ofchildrenaged7-8 years and $18.20 \%$ aged $11-12$ years had myopia. ${ }^{20,21}$

\section{CONCLUSION}

Ocular morbidities are common in children in the 
KavhrepalanchowkDistrictwithexternaleyeinfections beingthemostcommon problem, probablyduetoalack ofgoodhygienicpractice.Schoolawarenessprogrammes aboutpersonalhygienemayalsohelptoreduceexternal eye infections. Vitamin A related ocular morbidity was notobservedinthisstudy. Theethnicvariationofocular morbidityisanimportantobservationmostlyforrefractive errors and strabismus.

\section{ACKNOWLEDGEMENT}

We would like to acknowledge the Community ProgrammesDepartmentofDH-KUHforarrangingthe schoolvisits.OursincerethankstoDrPrashantKhatiwada.

\section{REFERENCES}

1. Holden BA, Resnikoff S. The role of optometry in Vision 2020. J Community Eye Health 2002;15:33-6.

2. Nepal BP, Koirala S, Adhikary S, Sharma AK. Ocular morbidityinschoolchildreninKathmandu.BrJOphthalmol 2003;87:531-34.

3. Niroula DR, Saha CG. Study on the refractive errors of schoolgoingchildrenofPokharacityinNepal.Kathmandu Univ Med J 2009;7:67-72.

4. Zhao J, Pan X, Sui R, Sperduto RD, Ellwein LB. Refractive errorstudyinchildren:resultsfromShunjiDistrict, China. Am J Ophthalmol. 2000;129:427-35.

5. Maul E, Barroso S, Munoz SR, et al. Refractive error study inchildren:resultsfromLaFlorida, Chile.AmJOphthalmol 2000;129:445-54.

6. Pokharel GP, Negrel AD, MunozSR, Ellwein LB. Refractive Error Study in Children: results from Mechi Zone, Nepal. Am J Ophthalmol 2000;129:436-44.

7. Karki KJD, Karki M. Refractive error profile - a clinical study. Kathmandu Univ Med J 2003;2:208-12.

8. Population division, Ministry of health and population, government of Nepal. Demographic and Health Survey, Nepal; 2007. p.183.

9. Ajaiyeoba $\mathrm{Al}$, Isawumi MA, Adeoye AO, Oluleye TS. PrevalenceandCausesofEyeDiseasesamongstStudents in South-Western Nigeria. Annals of African Medicine 2006;5:197-03.

10. Yoseph W, Samson B. Screening of ocular abnormalities and subnormalvision in schoolchildren ofButajiratown, southern Ethiopia. Ethiop J Health Dev 2001;15:125-30.

11. Shaffi M, Bejiga A. Common eye diseases in children of ruralcommunityinGorodistrict,CentralEthiopia.EthiopJ Health Dev 2005;19:148-52.
12. Naidoo KS, Raghunandan A, Mashige KP, Govender $P$, Holden BA, Pokharel GP, Ellwein LB. Refractive Error and Visual Impairment in African Children in South Africa. Investigative Ophthalmology \& Visual Science 2003;44:3764-70.

13. KumarR,DabasP,MehraM,IngleGK,SahaandR,Kamlesh. OcularmorbidityamongstprimaryschoolchildreninDelhi. HealthandPopulation-Perspectivesandlssues2007;30:22229.

14. Kehinde AV,Ogwurike SC, EruchaluUV,PamV, SamailaE. SchooleyehealthscreeninginKaduna-NorthernNigeria. Nigerian Journal of Surgical Research 2005;7:191-94.

15. Murthy GV, Gupta SK, Ellwein LB, Muñoz SR, Pokharel GP, Sanga L, Bachani D. Refractive error in children in an urbanpopulationinNewDelhi.InvestOphthalmolVis Sci 2002;43:623-31.

16. Dandona R, Dandona L, Srinivas $M$, Sahare $P$, Narsaiah $S$, Muñoz SR, Pokharel GP, Ellwein LB. Refractive error in childreninaruralpopulationinIndia.InvestOphthalmolVis Sci 2002;43:615-22.

17. Limburg H, Vaidyanathan K, Dalal HP. Cost effective screening of school children for refractive errors. World Health Forum 1995;16:173-78.

18. Kalikivayi V, Naduvilath TJ, BansalAk, Dandona L. Visual impairment in school children in southern India.Indian J Ophthalmol 1997;45:129-34.

19. Khalaj M, Gasemi M, Zeidi IM. Prevalence of Refractive Errors in Primary School Children [7-15 Years] of Qazvin City. Eur J Sci Res 2009;28:174-85.

20. Cung KM, Mohidin N, Yeow PT, Tan LL, O'Leary D. PrevalenceofvisualdisordersinChineseschoolchildren. Optom Vis Sci 1996;73:695-700.

21. Edward MH. The development of myopia in Hong Kong children between the ages of 7 and 12 years: a five-year longitudinalstudy.OphthalmicPhysioOpt1999;19:286-94. 